\title{
Cost-effectiveness of conventional cytology and HPV DNA testing for cervical cancer screening in Colombia
}

\author{
Oscar Andrés-Gamboa, MD, (1)Liliana Chicaíza, PhD, (1,2) Mario García-Molina, PhD, ${ }^{(1,2)}$ \\ Jorge Díaz, MSc, (1,2) Mauricio González, MD, (I) Raúl Murillo MD, MSc, (I) \\ Mónica Ballesteros MD, MSc, ${ }^{(1)}$ Ricardo Sánchez MD, MSc. ${ }^{(1,2)}$
}

\author{
Andrés-Gamboa O, Chicaíza L, García-Molina M, Díaz J, \\ González M, Murillo R, Ballesteros M, Sánchez R. \\ Cost-effectiveness of conventional cytology and HPV DNA \\ testing for cervical cancer screening in Colombia \\ Salud Publica Mex 2008;50:276-285.
}

\begin{abstract}
Objective: To assess cost-effectiveness of conventional cytology and HPV DNA testing for cervical-cancer screening in Colombia. Material and Methods: The National Cancer Institute of Colombia ( NCIC) in 2007 developed a Markov model on the natural history of cervical cancer; no screening, conventional cytology, and HPV DNA testing were compared. Only direct costs were used. Outcomes comprise cervical cancer mortality, years of life saved, and lifetime costs. Discounted incremental cost-effectiveness ratios were estimated and sensitivity analyses were conducted for key parameters. Results: Depending on the screening strategy a $69-81 \%$ mortality reduction might be expected. The HPV DNA testing every five years is a cost-effective strategy (Incremental Cost-Effectiveness Ratio (ICER): USD \$44/YLS) if the cost per test is under USD\$3I. The effectiveness was sensitive to coverage and primarily to follow-up. Conclusions: HPV DNA testing is a cost-effective alternative for screening in Colombia. Not only high coverage but high follow-up rates are critical for successful screening programs.
\end{abstract}

Key words: uterine cervical neoplasms; cost-benefit analysis; mass screening; Colombia
Andrés-Gamboa O, Chicaíza L, García-Molina M, Díaz J, González M, Murillo R, Ballesteros M, Sánchez R.

Costo-efectividad de la citología y la tamización con pruebas de ADN-VPH para cáncer de cuello uterino en Colombia. Salud Publica Mex 2008;50:276-285.

\section{Resumen}

Objetivo: evaluar el costo-efectividad de la citología convencional y la prueba de ADN-VPH para tamización de cáncer cervical en Colombia. Material y métodos: el Instituto Nacional de Cancerología de Colombia construyó en 2007 un modelo de Markov de historia natural del cáncer cervical. Se comparó “no tamización”, citología convencional y prueba de ADN-VPH. Se utilizaron costos directos. Los desenlaces fueron mortalidad, años de vida ganados y costos. Se calcularon razones de costo-efectividad incremental. Se realizaron análisis de sensibilidad para parámetros clave. Resultados: la mortalidad se redujo 69-81\% según la estrategia. La tamización con ADN-VPH cada cinco años es costo-efectiva (ICER (Razón de Costo-Efectividad incremental por sus siglas en inglés): 44 dólares por año de vida saludable) si los costos por prueba son menores a $3 \mathrm{I}$ dólares. La efectividad fue más sensible al seguimiento que a la cobertura. Conclusiones: La tamización con prueba ADN-VPH es costo-efectiva para Colombia. No solamente altas coberturas, sino también altos porcentajes de seguimiento son críticos para el éxito de la tamización.

Palabras clave: neoplasias del cuello uterino; tamizaje masivo; análisis costo-beneficio; Colombia

(I) National Cancer Institute of Colombia.

(2) National University of Colombia.

Received on: September 28, 2007 - Accepted on: March 14, 2008

Address reprint requests to: MD. Oscar Andrés Gamboa. Clinical Research Group, National Cancer Institute of Colombia. Av. !ra. no. 9-85, Bogotá Colombia. E-mail:ogamboa@cancer.gov.co 
C ervical cancer is the second cause of cancer-related deaths in women. There are approximately 407000 new cases worldwide every year $181 \%$ occurring in developing countries) and it is the leading cause of death from cancer among Colombian women and the second among Latin American women. ${ }^{1}$

The incidence of cervical cancer has declined substantially in developed nations due to the success of widespread cytology programs; ${ }^{2}$ however, this result has not been obtained in most developing countries.,4 New technologies for early detection are promising but costly, and due to severe resource constraints, decisionmakers need to estimate costs and effectiveness in order to determine the best alternatives. ${ }^{5}$

Despite several economic studies that analyze alternatives for cervical cancer screening, few have been conducted in Latin America and none in Colombia, ${ }^{6-10}$ and previous results on costs and effectiveness for various screening alternatives cannot be directly applied from other countries. Additionally, prior studies focused on screening tests or type of program (opportunistic or organized $)^{11}$ and no direct assessments of program component effectiveness have been regularly done other than for coverage.

In Colombia, early detection of cervical cancer is done on a 1-1-3 cytology strategy (annual conventional cytology until two consecutive negative smears and every three years afterwards), but without organized programs. ${ }^{12}$ Currently there is no available information on screening performance other than the lack of impact on cervical cancer mortality and some reports about the yearly number of cytology tests. ${ }^{4}$ This study performs an economic evaluation of different cervical cancer screening alternatives and assesses the effect of coverage and follow-up of abnormal screening results on screening effectiveness in Colombia.

\section{Material and methods}

The study was approved by the IRB at the National Cancer Institute in Colombia (NCIC). We developed a Markov model to simulate the natural history of cervical neoplasias (DATA 4.0 ()) including five models for various screening strategies. The outcomes comprise the reduction of cervical cancer mortality, years of life saved, and lifetime costs. We determined incremental cost-effectiveness ratios (ICER) $)^{13}$ and costs and benefits were discounted by a 3\% annual rate. A strategy was considered cost-effective if the cost per year of life saved was under the Colombian per capita GDP (US\$3.200)..$^{14,15}$

Sensitivity analyses were done for sensitivity and specificity of screening tests, as well as for screening, diagnoses, and treatment costs. The effect of coverage and follow-up of positive results on mortality from cervical cancer was assessed for all screening strategies.

\section{Natural history model}

The model incorporates the natural history of cervical cancer (figure 1). Ahypothetical cohort of unscreened women without a history of cervical neoplasia was included in the model. The women may transit between stages according to probabilities for annual cycles, up to completing the life expectancy for Colombian women (76 years). ${ }^{16}$

The model's predictions were compared with published data on incidence of $\mathrm{HPV},{ }^{17}$ cervical intraepithelial lesions, ${ }^{18}$ and cancer among Colombian women, ${ }^{19}$ as well as with data on mortality from cervical cancer ${ }^{20}$ and previously published models. ${ }^{21,22}$

\section{Natural history and screening model assumptions}

1. All women are 15 years old and HPV infection naive at admission.

2. All cases of cervical neoplasia occur in presence of high-risk HPV infection. Low-risk HPV infections do not progress to cervical cancer. ${ }^{23,24}$

3. HPV infection is age-dependent.

4. Probabilities of regression/progression for HPV infection, as well as for low- and high-grade cervical intraepithelial lesions (LSIL and HSIL) are age-dependent and related to HPV type. . $^{17,18,25}$

5. Women with LSIL do not receive treatment.

6. Once invasive cancer develops, the disease does not regress; women can remain in the same stage, progress to the next stage, or die from cancer or other causes.

7. Five years after treatment for cervical cancer without relapse, the probability of death matches the general population risk. ${ }^{21}$

8. Coverage is defined as the likelihood of screening in the last year.

9. Follow-up is defined as the likelihood of being diagnosed and treated after a positive screening result.

10. All women with positive screening results (other than cancer) return after treatment to the screening program in the model.

11. Program-related and implementation costs were not considered.

\section{Screening strategies}

The strategies included were determined by a national Colombian panel of scientific advisors ${ }^{12}$ and correspond 


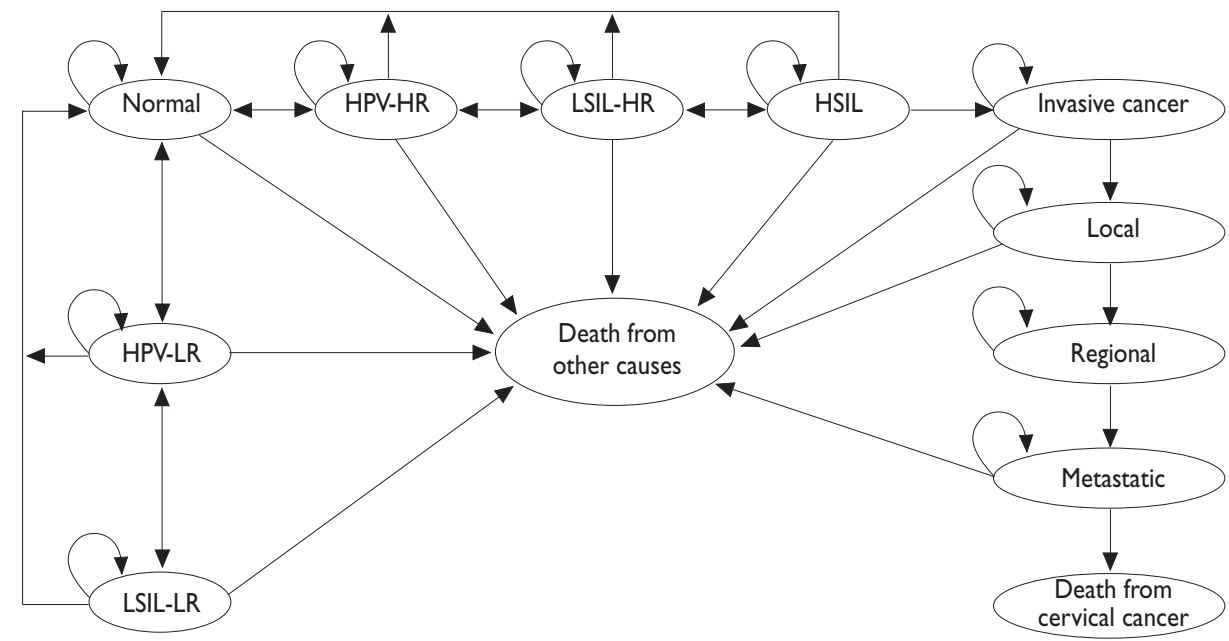

HPV denotes human papillomavirus infection. This status has two categories depending on HPV types: high (HR) or low-risk (LR) for cervical cancer. LSIL denotes low-grade intraepithelial lesion. This status has two categories depending on HPV type: HR or LR for cervical cancer. HSIL denotes high-grade intraepithelial lesion

Source: Own computations. National Cancer Institute, Colombia, 2007

Figure I. Natural history of Cervical CANCer

to those considered to have the greatest feasibility for application based on scientific evidence and conditions that are unique to the Colombian health system:

- Cytology at 1-1-3 intervals. Atypical squamous cells of uncertain significance (ASCUS) received HPVDNA testing (Hybrid Capture II). LSIL or more and HPV-positive women went to colposcopy.

- Annual conventional cytology until three consecutive negative smears and every three years afterwards (1-1-1-3 interval). Management of LSIL or more and ASCUS as described for the 1-1-3 interval.

- HPV-DNA testing (Hybrid-capture II) every three or five years (as independent strategies) followed by cytology in positive results. ASCUS or more went to colposcopy.

Screening is based on a three-visit program (screening, diagnosis, and treatment). The age range for cytology-based screening is 21 to 69 years and for HPV-DNA, 30 to 69 years.

\section{Clinical data}

Data on natural history were taken from the Bogota cohort study, ${ }^{17,25}$ previous cost-effectiveness models, ${ }^{21,26}$ and systematic reviews about the natural history of cervical cancer. ${ }^{18,27,28}$

The performance of screening tests and the effectiveness of treatment for HSIL were defined based on published literature. ${ }^{29-31}$ Number of years of life saved was used as an indicator of effectiveness for screening strategies. Cervical cancer mortality is a result of the model rather than an initial parameter, thus, reduction in mortality rates were not assumed a priori.

The likelihood of mortality from causes other than cervical cancer is age-sensitive according to official data for Colombia. ${ }^{20}$ Probabilities for transition among states of natural history were adjusted annually. ${ }^{32}$ (Table I)

\section{Cost data}

The economic evaluation was from the payer's perspective. Costs are based on a study by the National Cancer 
Table I

Model Variables for Economic Evaluation. Cervical cancer in Colombia, 2007

Base Case Range Source

Annual incidence of high-risk HPV infection by age (years)*

\begin{tabular}{clll} 
Annual incidence of high-risk $\mathrm{HPV}$ infection by age (years) & \multicolumn{1}{l}{$(17)$} \\
15 & 0 & 0 & 0 \\
\hline 16 & 0.10 & 0.050 & 0.20 \\
\hline 17 & 0.12 & 0.060 & 0.24 \\
\hline 18 & 0.15 & 0.075 & 0.30 \\
\hline 19 & 0.17 & 0.085 & 0.34 \\
\hline 20 & 0.15 & 0.075 & 0.30 \\
\hline 21 & 0.12 & 0.060 & 0.24 \\
\hline 31 & 0.07 & 0.035 & 0.14 \\
\hline 50 & 0.072 & 0.036 & 0.14 \\
\hline 85 & 0.0004 & 0.0002 & 0.0008
\end{tabular}

Annual incidence of low-risk HPV infection by age (years)(17)

\begin{tabular}{clll} 
Annual incidence of low-risk $\mathrm{HPV}$ infection by age (years) $(17)$ \\
\hline 15 & 0 & 0 & 0 \\
\hline 16 & 0.012 & 0.006 & 0.024 \\
\hline 17 & 0.024 & 0.012 & 0.048 \\
\hline 18 & 0.037 & 0.018 & 0.074 \\
\hline 19 & 0.049 & 0.024 & 0.098 \\
\hline 20 & 0.061 & 0.031 & 0.122 \\
\hline 21 & 0.006 & 0.003 & 0.120 \\
\hline 51 & 0.021 & 0.011 & 0.042 \\
\hline 82 & 0.052 & 0.026 & 0.104 \\
\hline 83 & 0.053 & 0.027 & 0.106 \\
\hline 84 & 0.054 & 0.027 & 0.108 \\
\hline 85 & 0.055 & 0.028 & 0.110
\end{tabular}

\begin{tabular}{ccccc} 
Regression from low-risk HPV infection to healthy & & (25) \\
\hline I5-85 years & 0.82 & 0.70 & 0.90
\end{tabular}

Regression from high-risk HPV infection to healthy

$$
\begin{array}{llll}
15-85 \text { years } & 0.70 & 0.60 & 0.80
\end{array}
$$

Progression from high-risk HPV to LSIL

$$
\begin{array}{lllll}
\hline 15-85 \text { years } & 0.072 & 0.053 & 0.112 & (2 I)
\end{array}
$$

Progression from low-risk HPV to LSIL

$$
15-85 \text { years } \quad 0.036
$$

\begin{tabular}{|c|c|c|c|c|}
\hline \multicolumn{4}{|c|}{ Progression from high-risk HPV to HSIL ** } & $(|8,2|)$ \\
\hline 15 years & 0.032 & 0.016 & 0.064 & \\
\hline 85 years & 0.042 & 0.021 & 0.084 & \\
\hline Regression from LSIL to healthy* & & & & \\
\hline 15 years & 0.160 & 0.141 & 0.235 & \\
\hline 85 years & 0.081 & 0.067 & 0.160 & \\
\hline Regression from LSIL to HPV*** & & & & (2I) \\
\hline 15 years & 0.160 & 0.141 & 0.235 & \\
\hline 85 years & 0.082 & 0.067 & 0.160 & \\
\hline Progression from LSIL to HSIL & & & & $(21,28)$ \\
\hline 15 years & 0.017 & 0.017 & 0.057 & \\
\hline 85 years & 0.069 & 0.066 & 0.109 & \\
\hline Regression from HSIL to healthy & & & & $(21,28)$ \\
\hline $15-85$ years & 0.069 & 0.058 & 0.109 & \\
\hline Regression from HSIL to HPV & & & & (26) \\
\hline $15-85$ years & 0.05 & 0.00 & 0.10 & \\
\hline Regression from HSIL to LSIL & & & & (2I) \\
\hline $15-85$ years & 0.069 & 0.058 & 0.109 & \\
\hline
\end{tabular}

Progression from high-risk HPV to HSIL **
Base Case Range

Source

Progression from HSIL to stage I cervical cancer ${ }^{\ddagger}$

\begin{tabular}{ccccc}
\hline 15 years & 0.010 & 0.005 & 0.020 & $(18,21,23)$ \\
\hline 30 years & 0.020 & 0.010 & 0.040 & \\
\hline 85 years & 0.005 & 0.025 & 0.097
\end{tabular}

Progression cervical cancer

(26)

$$
\text { Stage I to stage II cervical cancer }
$$

$$
\begin{array}{llll}
15-85 \text { years } & 0.437 & 0.400 & 0.450
\end{array}
$$

Stage II to stage III cervical cancer

$15-85$ years

$\begin{array}{lll}0.535 & 0.500 & 0.550\end{array}$

Stage III to stage IV cervical cancer

$\begin{array}{lrrr}15-85 \text { years } & 0.683 & 0.650 & 0.700\end{array}$

Symptoms annual probabilities

\begin{tabular}{llll} 
Symptoms annual probabilities & & & \\
\hline Stage I cancer & 0.15 & 0.12 & 0.18 \\
\hline Stage II cancer & 0.23 & 0.20 & 0.25 \\
\hline Stage III cancer & 0.60 & 0.67 & 0.73 \\
\hline Stage IV cancer & 0.90 & 0.87 & 0.93
\end{tabular}

(26)

Survival

\begin{tabular}{cccc}
\hline $\begin{array}{c}\text { Stage I cancer } \\
\text { I year }\end{array}$ & 0.967 & 0.85 & 0.99 \\
\hline 2 year & 0.952 & 0.83 & 0.97 \\
\hline 3 year & 0.954 & 0.83 & 0.97 \\
\hline 4 year & 0.976 & 0.85 & 0.99 \\
\hline 5 year & 0.976 & 0.85 & 0.99
\end{tabular}

\begin{tabular}{cccc} 
Stage II cancer & & & \\
\hline I year & 0.907 & 0.78 & 0.92 \\
\hline 2 year & 0.876 & 0.75 & 0.89 \\
\hline 3 year & 0.922 & 0.80 & 0.94 \\
\hline 4 year & 0.933 & 0.81 & 0.95 \\
\hline 5 year & 0.960 & 0.84 & 0.98
\end{tabular}

\begin{tabular}{cccc}
$\begin{array}{c}\text { Stage III cancer } \\
\text { I year }\end{array}$ & 0.707 & 0.58 & 0.72 \\
\hline 2 year & 0.739 & 0.61 & 0.75 \\
\hline 3 year & 0.861 & 0.74 & 0.88 \\
\hline 4 year & 0.923 & 0.80 & 0.94 \\
\hline 5 year & 0.914 & 0.79 & 0.93
\end{tabular}

Stage IV cancer

\begin{tabular}{cccc}
$\begin{array}{c}\text { I year } \\
2 \text { year }\end{array}$ & 0.399 & 0.27 & 0.41 \\
\hline 3 year & 0.498 & 0.37 & 0.51 \\
\hline 4 year & 0.764 & 0.64 & 0.78 \\
\hline 5 year & 0.865 & 0.74 & 0.88 \\
\hline & 0.859 & 0.73 & 0.87
\end{tabular}

Cytology ASCUS cut point

\begin{tabular}{llll}
\hline Sensitivity & 72.7 & 50.0 & 81.5 \\
\hline Specificity & 91.9 & 90.2 & 93.6
\end{tabular}

(29)

\begin{tabular}{llll} 
HPV-DNA testing & & & \\
\hline Sensitivity & 90 & 86.4 & 93.7 \\
\hline Specificity & 86.5 & 83.1 & 89.8
\end{tabular}

\begin{tabular}{lllll} 
Colposcopy & & & & $(30)$ \\
\hline Sensitivity & 87 & 24 & 90 & \\
\hline Specificity & 87 & 68 & 97
\end{tabular}

$\begin{array}{lllll}\text { LEEP efficacy } & 95 & 91 & 98 & \text { (3I) }\end{array}$

\footnotetext{
* Rates were turned into annual probabilities

₹ For data on transition probabilities by age category please consult the author
} 
Institute of Colombia, ${ }^{33}$ updated for 2007 (table II). We analyzed direct costs for various screening strategies, diagnostic procedures, treatment of HSIL (cold-knife conization), and treatment of cervical cancer (local, regional, and distant invasive cancer). Cancer treatmentrelated costs include staff, surgical procedures, medical treatments, and treatment for complications. Diagnosis costs include those for false positive results. Estimations were based on a micro-costing technique. ${ }^{33}$

Program-related costs were not included, except those for quality control such as second reading of Pap smears or additional kits for HPV-DNA testing.

\section{Results}

\section{Cost-effectiveness of screening alternatives}

Cervical cytology at a 1-1-1-3 interval reduced the lifetime risk of death from cervical cancer by $81 \%$, cervical cytology at 1-1-3 by 79\%, HPV-DNA testing every three years by $77 \%$, and HPV-DNA testing every five years by $69 \%$. Cervical cancer screening increases life expectancy from 2.9 to 3.5 months depending on the screening strategy.

Without discount, the most costly and effective strategy was cervical cytology at a 1-1-1-3 interval and

Table II

\section{Costs and Ranges Used in Sensitivity Analyses. Cervical cancer. National Cancer Institute In Colombia, 2007}

\begin{tabular}{|c|c|c|c|}
\hline \multirow{2}{*}{$\begin{array}{l}\text { Variable } \\
\text { Cytology }\end{array}$} & \multirow{2}{*}{$\begin{array}{r}\text { Base, USD } \\
6.34\end{array}$} & \multicolumn{2}{|c|}{ Range, USD } \\
\hline & & 5.90 & 12.67 \\
\hline HPV test & 12.10 & 8.30 & 62.53 \\
\hline Colposcopy & 45.61 & 42.46 & 91.22 \\
\hline Colposcopy + biopsy & 135.95 & 126.54 & 271.89 \\
\hline Treatment for HSIL (LEEP) & 223.68 & 208.21 & $|, 285.8|$ \\
\hline Treatment for stage I cancer & $2,950.50$ & $2,746.43$ & $5,901.00$ \\
\hline Treatment for stage II cancer & $3,745.50$ & $3,486.44$ & $7,205.20$ \\
\hline Treatment for stage III cancer & $3,745.50$ & $3,486.44$ & $7,205.20$ \\
\hline Treatment for stage IV cancer & $3,745.50$ & $3,486.44$ & $7,205.20$ \\
\hline Follow-up for $\mathrm{HSIL}^{\ddagger}$ & 955.35 & 173.09 & $|, 3| 3.6 \mid$ \\
\hline Follow-up for invasive cancer & $\mathrm{I}, 623.42$ & $\mathrm{I}, 5 \mathrm{II} . \mathrm{I} 4$ & $2,435.13$ \\
\hline Diagnosis verification for LSIL HSIL & 231.52 & $215.5 \mid$ & 389.63 \\
\hline \multicolumn{4}{|c|}{$\begin{array}{l}\text { * Costs are presented in US dollars (as of December 2006, US } \$ \text { I equals } \\
\$ 2,238.79 \text { Colombian pesos) } \\
\text { ₹ Follow-up strategies were: I visit every } 4 \text { months in I year, followed } \\
\text { by I visit every } 6 \text { months during } 5 \text { years, followed by one annual visit } \\
\text { during } 10 \text { years. The costs included are: evaluation by specialist in office } \\
\text { visits, cytology in each visit, colposcopy in each visit, and biopsy in about } \\
5 \% \text { of colposcopies }\end{array}$} \\
\hline
\end{tabular}

Source: FEDESALUD, update National Cancer Institute, Colombia, 2007 the least costly and least effective was HPV-DNA testing every five years (figure 2). Without discount, cytology at 1-1-3 intervals has extended dominance, which indicates a greater ICER when transferring from HPV-DNA testing every three years to cytology at 1-1-3 intervals (USD $\$ 8,091)$ than for transferring from this regimen to cytology 1-1-1-3 (USD $\$ 7,444)$.

With discount, the least costly per year of life saved was HPV-DNA testing every five years (USD\$44/YLS). HPV-DNA testing every three years has the highest lifetime cost (USD \$367.6) and it is as effective as HPVDNA every five years. HPV-DNA screening dominates cytology-based screening (table III).

\section{Sensitivity analysis}

The results, without discount, were sensitive to costs, performance of screening tests, and diagnosis and treatment costs for HSIL. However, when the parameters were modeled in a plausible range, only costs for HPV-

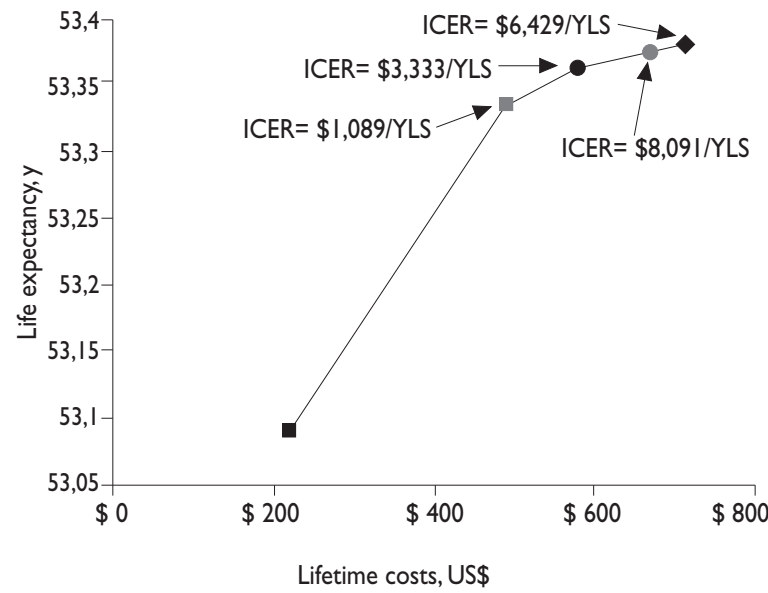

- No screening

HPV every 5 years

- HPV every 3 years

- Cervical cytology II3

- Cervical cytology III3

YLS, years of life saved; HPV, human papillomavirus; ICER, incremental costeffectiveness ratio. Strategies located on the efficiency curve dominate those located to right of the curve because they are more effective and/or cost less. The strategy with cervical cytology I-I-3 is dominated by the other strategies due to a greater ICER than the next- best-strategy.The ICER is the reciprocal of the slope of the line connecting the two screening strategies under comparison

Figure 2. Lifetime cost AND Benefits of SCREening for different strategies (no discount). Cervical cancer. National Cancer Institute in Colombia, 2007 
Table III Costs, years of life saved, cost-effectiveness ratios, and inCRemental cost-effectiveness ratio for various
screening strategies. Cervical Cancer. National Cancer InStitute in Colombia, 2007

$\begin{array}{ccccccc} & \text { Mean lifetime } & \text { Incremental } & \text { Mean life time } & \text { Mean gain in life } & \text { CIE } & \text { ICER, US } \\ \text { Screening strategy } & \text { cost, US\$* } & \text { costs, US } \$ & \text { xpectancy, years } & \text { expectancy } & \text { US } \$ / Y L S & \$ / Y L S\end{array}$

A. No discounted variables

\begin{tabular}{lrrrrrr} 
No screening & $\$ 223$ & - & 53.09 & - & $\$ 4$ & - \\
\hline HPV every 5 years & $\$ 49$ I & $\$ 268$ & 53.33 & 0.246 & $\$ 9$ & $\$ 1,089$ \\
\hline HPV every 3 years & $\$ 58$ I & $\$ 90$ & 53.36 & 0.027 & $\$ 1$ I & $\$ 3,333$ \\
\hline Cervical cytology I-I-3 & $\$ 670$ & $\$ 89$ & 53.37 & 0.01 I & $\$ 13$ & $\$ 8,09$ I \\
\hline Cervical cytology I-I-I-3 & $\$ 715$ & $\$ 45$ & 53.38 & 0.007 & $\$ 13$ & $\$ 6,429$
\end{tabular}

\begin{tabular}{llccccc} 
& \multicolumn{7}{c}{ Strategies each compared with no screening } & & & \\
No screening & $\$ 223$ & - & 53.09 & - & $\$ 4$ & - \\
\hline HPV every 5 years & $\$ 49$ I & $\$ 268$ & 53.33 & 0.246 & $\$ 9$ & $\$ 1,089^{\#}$ \\
\hline HPV every 3 years & $\$ 58 I$ & $\$ 358$ & 53.36 & 0.273 & $\$ 1 I$ & $\$ 1,308^{\#}$ \\
\hline Cervical cytology I-I-3 & $\$ 670$ & $\$ 447$ & 53.37 & 0.284 & $\$ 13$ & $\$ 1,574^{\#}$ \\
\hline Cervical cytology I-I-I-3 & $\$ 715$ & $\$ 492$ & 53.38 & 0.291 & $\$ 13$ & $\$ 1,687^{\#}$
\end{tabular}

B. Discounted variables ${ }^{\&}$

\begin{tabular}{|c|c|c|c|c|c|c|}
\hline No screening & $\$ 130.9$ & - & 28.4 & - & $\$ 4.6$ & - \\
\hline HPV every 5 years & $\$ 293.9$ & $\$ 163.0$ & 32.1 & 3.7 & $\$ 9.2$ & $\$ 44$ \\
\hline Cervical cytology I-I-3 & $\$ 338.6$ & $\$ 44.7$ & 28.5 & -3.6 & $\$ 11.9$ & (Dominated) \\
\hline Cervical cytology I-I-I-3 & $\$ 361.8$ & $\$ 67.9$ & 28.6 & -3.5 & $\$ 12.7$ & (Dominated) \\
\hline HPV every 3 years & $\$ 367.6$ & $\$ 73.7$ & 32.11 & 0.01 & $\$ 11.5$ & $\$ 7,370$ \\
\hline
\end{tabular}

\begin{tabular}{|c|c|c|c|c|c|c|}
\hline \multicolumn{7}{|c|}{ Strategies each compared with no screening } \\
\hline No screening & $\$ 130.9$ & - & 28.4 & - & $\$ 4.6$ & - \\
\hline HPV every 5 years & $\$ 293.9$ & $\$ 163.0$ & 32.1 & 3.7 & $\$ 9.2$ & $\$ 44^{\#}$ \\
\hline Cervical cytology I-I-3 & $\$ 338.6$ & $\$ 207.7$ & 28.5 & 0.1 & $\$ 11.9$ & $\$ 2,077^{\#}$ \\
\hline Cervical cytology I-I-I-3 & $\$ 361.8$ & $\$ 230.9$ & 28.6 & 0.2 & $\$ 12.7$ & $\$ 1,154^{\#}$ \\
\hline HPV every 3 years & $\$ 367.6$ & $\$ 236.7$ & 32.11 & 3.71 & $\$ 11.5$ & $\$ 64^{\#}$ \\
\hline
\end{tabular}

* Costs presented in USD (as of December 2006 USD $\$$ I equals $\$ 2,238.79$ Colombian pesos)

‡ Cost-effectiveness ratio $(\mathrm{C} / \mathrm{E})$ is defined as the cost of a specific strategy divided by its effectiveness

$\S$ Incremental cost-effectiveness ratio (ICER) is defined as the additional cost of a specific strategy divided by its additional clinical benefits, as compared with the next-less-expensive strategy (division of differences)

\# Cost per year of life saved (YLS) is defined as the additional cost (differences of costs) divided by additional effectiveness (differences in effectiveness) as compared with no screening

\& Discounting rate $3 \%$

DNA testing and cytology sensitivity had an effect on the rank.

Screening with HPV-DNA testing every five years is cost-effective if the cost per test is under USD $\$ 31$; otherwise the most cost-effective strategy is cytology 1-1-3. Furthermore, cytology-based strategies are dominated by HPV-DNA testing when the sensitivity is lower than
$57 \%$. The results with discounted variables were robust in sensitivity analyses.

Modeling the coverage from 25 to $100 \%$ does not affect the rank; however, a reduction in follow-up to under 30\% resulted in HPV-DNA testing dominance over cytology (irrespective of the cytology interval). Additionally, a reduction of 50\% in coverage with 100\% 
follow-up reduces the efficacy of screening from 5 to $8 \%$ according to the screening strategy, but a reduction of $50 \%$ in follow-up with $100 \%$ coverage reduces the screening efficacy from 22 to $32 \%$ (figure 3 ).

\section{Model validation}

The natural history model revealed a bimodal age distribution for high-risk HPV infection, as is described for the source of data from a Colombian cohort of women. ${ }^{17}$
Estimates from cross-sectional studies reveal a lag time between HPV infection and HSIL from 7 to 15 years, with a peak of HSIL around ages 25 to $30 .{ }^{18}$ Our model predicts an HSIL incidence of 600 per 100000 with no screening, with peaks at ages 22 and 53. Data reported by population-based cancer registries show incidence peaks of HSIL around ages 22 to $30 .^{18}$

Our model predicts a 125 per 100000 invasive cancer incidence at age 58 , greater than that reported for the unscreened population in the United States in 1930 $(61 / 100000$ at 60$)$, and similar to data from Germany
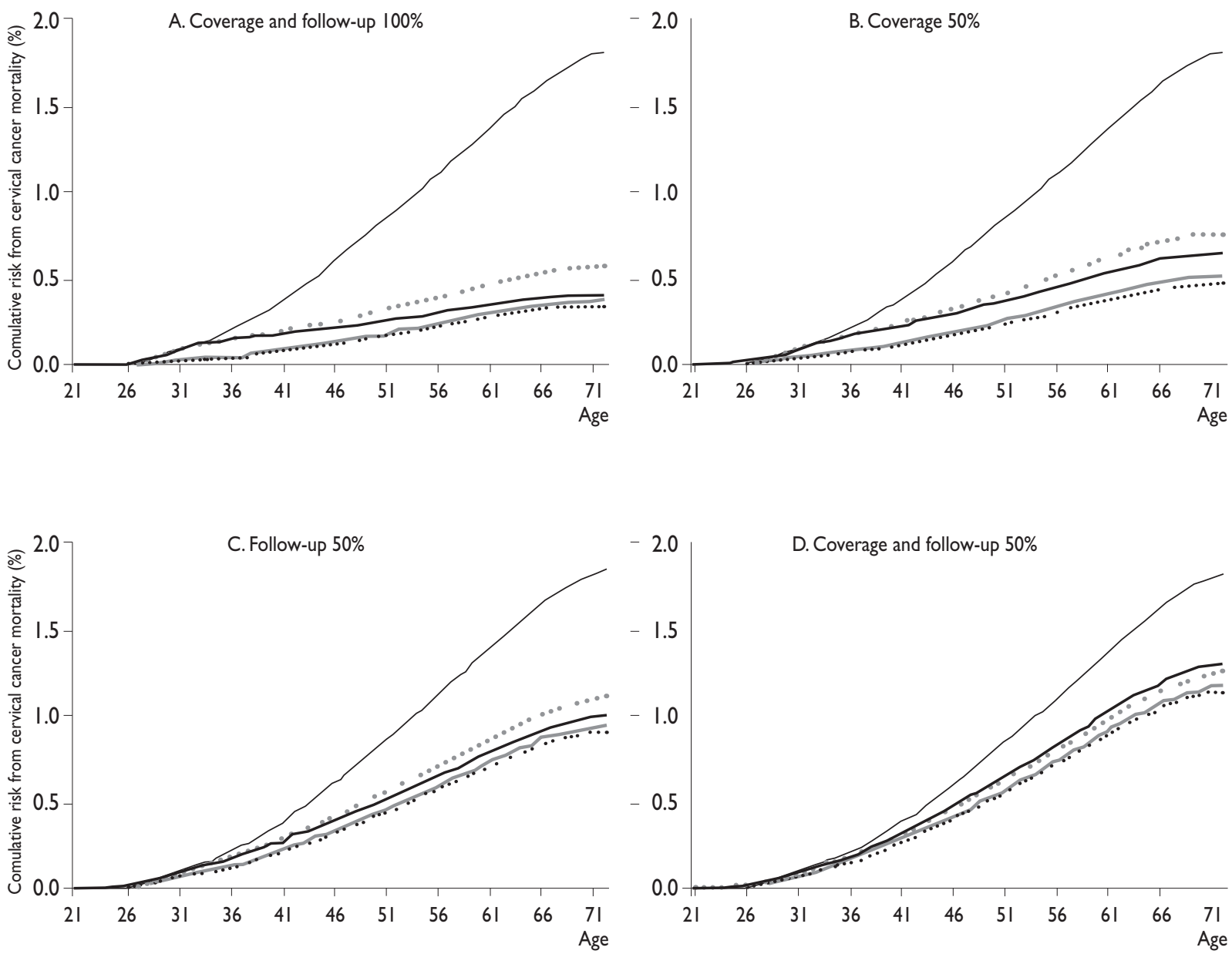

No screening

Cervical cytology II3

Cervical cytology III3

$\ldots . . H P V$ every 5 years

- HPV every 3 years

Figure 3. EFFECT OF COVERAGE AND FOLLOW-UP ON EFFECTIVENESS OF SCREENING STRATEGIES FOR REDUCING MORTALITY FROM cervical cancer. National Cancer Institute, Colombia, 2007 
in 1960 (110/100 000). ${ }^{34}$ The Cancer Registry of CaliColombia showed a 125.1 per 100000 incidence at age 60 between 1987 and 1991. ${ }^{19}$

The model predicted a peak of 51 per 100000 for cervical cancer mortality at age 60 , similar to data by the Cancer Registry of Cali between 1989 and 1993 (58.8 per 100 000). ${ }^{19}$

Goldie et al developed a Markov model simulating the natural history of HPV infection for a hypothetical cohort of North American women which predicted a $3.3 \%$ cervical cancer mortality with no screening, with an invasive cancer incidence peak of 67 per 100000 , and a prevalence peak of $7.1 \%$ for HSIL around ages 30 to $40 .{ }^{22}$ Myers et al predicted in their HPV natural history model an incidence peak for invasive cancer of 81 per 100000 at age 50 , and a prevalence peak of $2.6 \%$ for HSIL around age $40 .{ }^{21}$

The risk of death predicted by our model was $1.8 \%$, with an incidence peak for invasive cancer of 125 per 100000 at 58; and a prevalence peak for HSIL of $4 \%$ around age 30 . Thus, the predictions in our model are similar to the abovementioned models; the differences may be related to history of high-risk HPV infections, since our data are from Colombian women while other models include data from North American women.

\section{Discussion}

In an ideal scenario, cervical cancer mortality could be reduced by 69 to $81 \%$. This finding simulates previous reports ${ }^{21}$ and confirms the effectiveness of cervical cancer screening.

Only HPV-DNA testing every five years was costeffective (ICER USD \$44.4/YLS based on per capita GDP). Previous studies evidenced greater costs for HPV testing compared to cytology. $6,7,8,35$ Our findings could be explained by the cytological triage for HPV-positive women, ${ }^{36}$ since this procedure could significantly reduce costs associated with false positives and differs in this respect with published models. Different onset of screening, increased screening intervals, and greater reproducibility of HPV testing are additional contributions to the estimated reduction in lifetime costs for HPV-DNA testing.

Our study does not include program-related costs except those associated with quality control. It is not possible at the moment to clearly determine programrelated needs for HPV-testing; however, any alternative will require an organized program including personnel training, specimen or sample transportation, and followup activities, among others; thus, we determine that the final effect of program-related costs other than screening tests must not be greater than the assessed alternatives.
Nevertheless, given the fact that our results reflect ongoing strategies, the costs for implementing programs should be considered for decision-making because they may cost more than HPV testing.

HPV-DNA testing was cost-effective, with costs per test lower than or equal to USD $\$ 31$. Although prices for HPV tests are much higher today, a scenario of massive screening with this technology would allow for costs as used in the model. HPV-DNA testing has been associated with greater efficacy than cytology due to its greater sensitivity and reproductibility. ${ }^{11,37}$ We found a lower effectiveness for HPV screening every five years without discount but a lack of substantial differences in years of life saved compared to shorter intervals for the same test (every three years) and compared to cytological screening (figure 2). The difference may be attributable to the later onset for HPV-DNA screening in our model. Moreover, using an age-related differential sensitivity might lead HPV testing to render more savings in years of life due to its higher sensitivity in older women. ${ }^{38}$

We defined different onsets for screening strategies as recommended by the Colombian advisory panel. ${ }^{12}$ The dominance of HPV testing with discounted rates should be carefully interpreted because the differences in the onset could represent a bias in favor of strategies introduced lately. Additionally, the extended dominance of cytology at 1-1-1-3 intervals over 1-1-3 intervals cannot be understood as a direct comparison because this finding is based on the change from an initial HPV testing-based strategy; thus, comparing the two strategies directly may reveal different results.

The Colombian advisory panel recommended screening strategies and screening intervals, considering alternatives with greater feasibility for application in the country. Although other studies have included more screening strategies such as liquid-base cytology or visual inspection, it is less likely that these alternatives can be used extensively as the basis for cervical cancer screening in Colombia. ${ }^{39}$ Likewise, previous studies report promising results combining cytology and HPV-DNA tests, ${ }^{37}$ but recent publications show great benefits using HPV tests alone as the basis for screening, where cytology is an alternative to triage HPV-positive women as done in our model, and results in important savings. ${ }^{36}$

Some reports have revealed an inverse ratio between number of visits, costs, and effectiveness, ${ }^{2,3}$ which can also be interpreted in terms of program performance. Goldie et al have shown lower costs and greater effectiveness for strategies linking screening and treatment (reduced number of visits) in analyses in Peru. ${ }^{6,7}$ Additionally, an augment in lifetime screenings 
systematically generates an increase in costs associated with a variable increase in effectiveness. ${ }^{6}$ These results may indicate the burden of follow-up on program-related costs and its impact on effectiveness.

Comparing different strategies on the number of lifetime screenings is reasonable due to differences among possible scenarios for application, but despite the plausibility of reducing the number of visits, ${ }^{40}$ we restricted the alternatives in our study to those that would apply to current programs and evidence in order to generate suitable recommendations for routine healthcare services. Our programs are based on a threevisit strategy (screening, diagnosis, and treatment) and HPV-screening does not currently apply to a one-visit scenario.

Nevertheless, we assessed the effect of follow-up on program performance directly and found that a low follow-up for abnormal screening results has a greater impact on mortality than low coverage. Despite the synergic action between coverage and follow-up, the latter is not greatly affected by reductions in coverage (figure 3).

In Latin America, screening programs have made great efforts to achieve high coverage without similar efforts on follow-up. ${ }^{41}$ This view may be motivated by reports on screening performance from developed countries. ${ }^{3}$ Our results indicate a need for a greater effort on adequate follow-up, in spite of the obvious need for both components. Such results may also be associated with reports indicating a better cost-effectiveness ratio for organized than for opportunistic programs, ${ }^{11}$ but it requires a better understanding of the needs of an organized program.

Our analysis has several limitations. We combined data from various sources, different designs (cohort, clinical trials, population cancer registries, etc.), and different eligibility criteria for participating women. Additionally, these studies assessed results in short periods of time projected to long periods in our model. These limitations are due to the lack of country-specific information; nevertheless, this study is derived from a thorough review of the literature that encompasses recent results as to the benefits of screening tests for the natural history of infection.

This is the first analysis with primary data about the natural history of infection among Colombian women and is one of few studies developed in Latin America. ${ }^{6,10}$ Previous studies include little information from Latin American countries and others combine analyses of HPV vaccines and different screening strategies. The information from our study could be more likely to be used in short-term policy design due to the feasibility of introducing the tests and strategies in the model, while the incorporation of vaccines in regular immunization programs could take more time. If HPV vaccination is considered, additional analyses are required given its impact on screening performance as well as differential costs and effectiveness for interactive strategies.

An optimal cervical cancer screening policy needs to consider tests and screening alternatives as well as the effectiveness of different treatment options for precancerous lesions. The natural history model for cervical cancer must allow for a reasonable representation of heterogeneity among populations at risk and be able to incorporate data on accessibility, compliance, and feasibility with regard to a screening strategy. Clinical trials and cohort studies are not capable of incorporating all elements or assessing all possible strategies for all possible populations. These factors, along with the need for decision-making in a setting where information is incomplete, make analytical models useful tools for public health ${ }^{5}$ if the scope and limitations provided are adequately understood, suggesting future research for additional screening tests (visual inspection, rapid HPV testing) or new programmatic alternatives (HPV testing at younger ages, screening and treatment approaches, etc.).

\section{References}

I. Ferlay J, Bray F, Pisani P, Parkin DM. GLOBOCAN 2002 cancer incidence, mortality and prevalence worldwide. IARC CancerBase No. 5 version 2.0. Lyon: IARC Press,2004.

2. Lynge E, Madsen M, Engholm G. Effect of organised screening on incidence and mortality of cervical cancer in Denmark. Cancer Res 1989; 49(8): $2157-2160$.

3. Neto JE, Ramalho CM. Cervical Cancer in Laitn America. Semin Oncol 200I; 28(2): I88-197.

4. Pineros M, Hernandez G, Bray F. Increasing mortality rates of common malignancies in Colombia: an emerging problem. Cancer 2004;10I(I0):2285-2292.

5. Goldie SJ. Chapter 15: Public health policy and cost-effectiveness analysis. J Natl Cancer Inst Monogr 2003; 31: 102-I 10

6. Goldie SJ, Gaffikin L, Goldhaber JD, Gordillo A, Levin C, Wright T, et al. Cost-Effectiveness of cervical-cancer screening in five developing countries. N Engl J Med 2005; 353:2। 58-2I 68.

7. Goldie SJ, Kuhn L, Denny L, Pollack A, Wright T. Policy analysis of cervical cancer screening strategies in low-resource settings. JAMA 200I; 285(24): 3107-3126.

8. Legood R, Gray A, Mahé C, Javant k, Nene BM, Sankaranarayanan R, et al. Screening for cervical cancer in India: How much will it cost? A trial based analysis of the cost per case detected. Int J Cancer 2005; I 17: 981-987.

9. Holmes J, Hemmett L, Garfield S. The cost-effectiveness of human papillomavirus screening for cervical cancer. Eur J Health Econom 2005; 50: 30-37.

10. Flores Y, Bishai D, Lazcano E, Shah K, Lörincz A, Hernández M, et al. Improving cervical cancer screening in Mexico: results from the Morelos HPV Study. Salud Publica Mex 2003;45 Suppl 3:S388-S398. 
I I. Kim J], Leung GM,Woo P, Goldie SJ. Cost-effectiveness of organized versus opportunistic cervical cytology screening in Hong Kong.J Public Health 2004; 26(2): I30-I37.

12. Instituto Nacional de Cancerología. Recomendaciones para la tamización de neoplasias de cuello uterino en mujeres sin antecedentes de patología cervical (preinvasora o invasora) en Colombia. Bogotá: INC, 2007.

13. Prieto L, Sacristán JA,Antoñanzas F, Terrés CR, Pinto JL, Rovira J. Análisis coste-efectividad en la evaluación económica de intervenciones sanitarias. Med Clin (Barc) 2004; I 22 (I3):505-5I0.

14.World Health Organization. Macroeconomics and health: investing in health for economic development: report of the Commission on Macroeconomics and Health. Geneva:World Health Organization, 2001. 15. Departamento Administrativo Nacional de Estadística (DANE). Cuentas regionales. [Accesed February II, 2008].

Available at: www.dane.gov.co/files/investigaciones/pib/departamentales. 16. Departamento Administrativo Nacional de Estadística (DANE). Población: indicadores demográicos según departamento. [Accesed August 31, 2007]. Available at: www.dane.gov.co.

17. Muñoz N, Méndez F, Posso H, Molano M, van de Brule A, Muñoz A, et al. Incidence, duration, and determinants of cervical human papillomavirus infection in a cohort of Colombian women with normal cytological results. J Infect Dis 2004;190(I2):2077-2087.

18. Moscicki A, Schiffman M, Kjaer S,Villa L. Updating the Natural History of HPV and anogenital cancer.Vaccine 2006; 24(3): S42-S5I.

19. Cali S. Poblation Registry of Cancer. Health Faculty-Universidad del Valle Colombia. Cances Statistics [Accesed March II 5, 2008] Available at: http://rpcc.univalle.edu.coles/Mortalidad/frames.php.

20. Departamento Administrativo Nacional de Estadística (DANE).

Población: estadísticas vitales. [Accesed April 15, 2007]. Available at: www. dane.gov.co.

2I. Myers E, McCrory D, Nanda K, Bastian L, Matchar D. Mathematical Model for the Natural History of Human Papillomavirus Infection and Cervical Carcinogenesis. Am J Epidemiol 2000; I5I(I2):

II58-II7|.

22. Goldie SJ, Kim JJ,Wright TC. Cost-effectiveness of human papillomavirus DNA testing for cervical cancer screening in women aged 30 year or more. Obstet Gynecol 2004; 103: 619-63I.

23. Muñoz N, Bosch X, Sanjosé S, Herrero R, Castellsagué X, Shah KV, et al. Epidemiologic classification of human papillomavirus types associated with cervical cancer. N Engl J Med 2003; 348: 5I8-527.

24. Clifford G, Franceschi S, Diaz M, Muñoz N,Villa L. HPV typedistribution in women with and without cervical neoplastic diseases. Vaccine 2006; 24(3):S42-S5I.

25. Molano M, van de Brule A, Plummer M,Weiderpass E, Posso H,Aíslan A, et al. Determinants of Clearance of Human Papillomavirus Infections in Colombia Women with Normal Cytology: A Population-based, 5- year Follow- up study.Am J Epidemiol 2003; 158: 486-494.
26. Sanders G, Taira A. Cost-effectiveness of a potential vaccine for human papillomavirus. Emerg Infect Dis 2003; 9(I): 37-48.

27. Östör A. Natural History of Cervical Intraepiyhelial Neoplasis:A

Critical Review. Int J Gynecol Pathol 1993; 12: 186-192.

28. Melnikow J, Nuevo J,Willan A, Chan B, Howell L. Natural History of Cervical Squamous Intraepithelial Lesions:A meta-analysis. Obstet Gynecol 1998; 4(2): 727-735.

29. Koliopoulos G, Arbyn M, Martin-Hirsch P, Kyrgiou M, Prendiville W, Paraskevaidis E. Diagnostic accuracy of human papillomavirus testing in primary cervical screening: A systematic review and meta-analysis of nonrandomized studies. Gynecol Oncol 2007; I04(I):232-246.

30. Olaniyan O.Validity of colposcopy in the diagnosis of early cervical neoplasia: a review. Afr J Reprod Health 2002;6(3):59-69.

31. Hirsch M, Kitchener P. Surgery for Cervical Intraepithelial Neoplasis. The Cochrane Collaboration 1999. [Accesed May 15, 2007]. Available at: The Cochrane Library: www.cochrane.org.

32. Miller DK, Homan SM. Determining transition probabilities: confusion and suggestions. Med Decis Making 1994;14: 52-58.

33. Fundación para la Investigación y Desarrollo de la Salud y La Seguridad Social. Construcción de un sistema de pagos por paquetes de diagnóstico e intervención en enfermedades neoplásicas. Bogotá: Fedesalud, 2003.

34. McCrory DC, Matchar DB, Bastian L, Datta S, Hasselblad V, Hickey J, et al. Evaluation of cervical cytology. Evidence report/technology assessment no. 5. (Prepared by Duke University under contract no. 290-97-0014). Rockville, MD: Agency for Health Care Policy and Research, 1999. (AHCPR publication no. 99-E0I0).

35. Mandelblatt JS, Lawrence WF, Gaffikin L, Limpahayom KK, Lumbiganon P,Warakamin S, et al. Costs and benefits of different strategies to screen for cervical cancer in less-developed countries. J Natl Cancer Inst 2002;94(19): 1469-1 483.

36. Cuzick J, Szarewski A, Cubie H, Hulman G, Kitchener H, Luesley D, et al. Management of women who test positive for high-risk types of human papillomavirus: the HART study. Lancet 2003;362(9399): 187I- 1876.

37. Mandelblatt JS, Lawrence WF, Womack SM, Jacobson D,Yi B, Hwang YT, et al. Benefits and costs of using HPV testing to screen for cervical cancer. JAMA 2002;287(I8):2372-238I.

38. Cuzick J, Sasieni P, Davies P, Adams J, Normand C, Frater A, et al. A systematic review of the role of human papillomavirus testing within a cervical screening program. Health Technol Assess 1999;3(14):i-iv, I-204. 39. IARC. Handbooks of cancer prevention. Cervix cancer screening. Lyon: IARC Press, 2005.

40. Sankaranarayanan R, Esmy PO, Rajkumar R, Muwonge R, Swaminathan $R$, Shanthakumari $S$, et al. Effect of visual screening on cervical cancer incidence and mortality in Tamil Nadu, India: a cluster-randomised trial. Lancet 2007;370(9585):398-406.

4I. Goldie SJ, Kim JJ, Myers E. Chapter 19: Cost-effectiveness of cervical cancer screening.Vaccine 2006;24 Suppl 3:SI64-SI70. 